\title{
Correction: Route-specific association of progestin therapy and concurrent metformin use in obese women with complex atypical hyperplasia
}

Matsuo K, Mandelbaum RS, Ciccone M, et al. Route-specific association of progestin therapy and concurrent metformin use in obese women with complex atypical hyperplasia. Int $J$ Gynecol Cancer 2020;30:1331-9.

Since the publication of this article, the authors have noticed that the author name 'Heena Pursuwani' is incorrect. The correct author name is 'Heena Purswani'.

C Author(s) (or their employer(s)) 2020. No commercial re-use. See rights and permissions. Published by BMJ. Int J Gynecol Cancer 2020;30:2022. doi:10.1136/ijgc-2020-001362corr1

(D) Check for updates 